\title{
A Cloistered Entrepôt : Sir Tobie Matthew and the English Carmel in Antwerp
}

\author{
J.P. Vander Motten and Katrien Daemen-De Gelder
}

On 15 September 1616, Sir Dudley Carleton (1573-1632), the English ambassador at The Hague, provided his friend John Chamberlain with a short account of his journey from Spa to Brussels, Mechlin, Antwerp, and cities in the Northern Netherlands. Carleton had made his progress to Antwerp in the company of two knowledgeable guides, Sir Tobie Matthew (15771655), a former exile and art broker, and Sir William Trumbull (1576?-1635), King James' agent in Brussels. While he considered the sights of the archducal court in Brussels "the most pleasant that I have seene any where", he also remarked, tongue in cheek, that " $[t]$ he English Nunnes tooke it unkindly to be left unvisited, who take themselfs to be such pretious peeces (and so are sett owt and magnified by owr English Catholiques, whereof there we fownd many) that they thinck they should not have been so slighted; but we had neither time nor much desire to use that ceremonie." Carleton did not specify which order of English nuns hoped to be visited by their distinguished countrymen, but the reference was almost certainly to the Discalced Carmelites whose Brussels convent, founded in 1607, was in the immediate vicinity of the archducal court. ${ }^{2}$ The ambassador's sneer at the nuns' self-conceit, "magnified" by their co-religionists, testifies to the respect in which the Carmelites were held and the moral and cultural high ground which they felt their foundations occupied in early seventeenth-century society. Furthermore, Carleton's use of the verb "set out", denoting the act of displaying as well as publishing, neatly encapsulated a wide range of discursive and iconographical practices associated with the cult of St Teresa of Avila, also called Teresa of Jesus (1515-82).

The first Carmelite convents were founded in Spain by the companions and successors of Saint Teresa. Honoured by the Church as virgo seraphica [seraphic virgin] and doctrix mystica [doctor of mystical theology], she was the originator of the reformed, Discalced Carmelite Order, which revitalized the strict religious observance of primitive

\footnotetext{
${ }^{1}$ Sainsbury, 9-11.

${ }^{2}$ On the political and religious implications of this proximity, see van Wyhe, 457-87.
} 
Carmelite life. Her writings, including her autobiography, The Life of Teresa of Jesus, and her seminal works, The Interior Castle and The Way of Perfection, form an integral part of Spanish Renaissance literature and Christian mysticism. Truly remarkable - and celebrated to this day by Carmelites around the world - was Teresa's experience of the Transverberation, a mystical grace whereby Teresa's heart was spiritually perforated by a fiery dart. Of this ecstatic vision, which occurred around 1560, she writes in her autobiography:

I saw an angel close by me, on my left side, in bodily form. This I am not accustomed to see, unless very rarely. Though I have visions of angels frequently, yet I see them only by an intellectual vision, such as I have spoken of before... I saw in his hand a long spear of gold, and at the iron's point there seemed to be a little fire. He appeared to me to be thrusting it at times into my heart, and to pierce my very entrails; when he drew it out, he seemed to draw them out also, and to leave me all on fire with a great love of God. The pain was so great, that it made me moan; and yet so surpassing was the sweetness of this excessive pain, that I could not wish to be rid of it. ${ }^{3}$

This mystical subject engaged the attention of many a Baroque artist, including the "Teresian Poet" Richard Crashaw (1613-49), who revealed an intense preoccupation with the saint's "happy fire-works" -and by extension with his own personal spiritual state. ${ }^{4}$ Engravers, sculptors and painters took up the theme of the piercing of Teresa's heart: around 1614 Rubens painted a Transverberation for the church of the Discalced Carmelites in Brussels, and Bernini sculpted the dramatic Ecstasy of Saint Teresa, which still adorns the Cornaro Chapel of the Santa Maria della Vittoria in Rome. Having firmly established itself in Spain, the Teresian Order rapidly spread across Western Europe: religious houses were erected in Italy, France, the Southern Netherlands, and elsewhere. Summoned by the archdukes Albert and Isabella, the Venerable Ann of Jesus (1545-1621), a close associate of St Teresa's, started foundations in Brussels and Louvain in 1607, and in Mons in 1608. Together with Mary Lovel [Jane Roper, c. 1564-1628], she also established two Carmels in Antwerp, the second of which, founded in 1619 in the Hopland area of the city, was specifically meant for English-speaking women. ${ }^{5}$

In his September 1616 letter Carleton betrayed his irritation at the steadily growing English Catholic presence in the Southern Netherlands. But he could hardly have anticipated that very soon his travelling companion Sir Tobie Matthew was to carve out a career as a prolific Catholic writer deriving creative inspiration from the spiritual traditions of the English religious houses on the continent. The canon of Matthew's works largely consists of ascetical writings translated out of Spanish and Italian and published at St Omer in the

\footnotetext{
${ }^{3}$ Saint Teresa, 255-6.

${ }^{4}$ Crashaw, 103-7.

${ }^{5}$ On the troubled beginnings of the first Carmelite foundation, see Guilday, 358-70.
} 
$1620 \mathrm{~s}$ and $1630 \mathrm{~s}$. Although several of these have only been tentatively ascribed to him, two works of undisputable authorship provide evidence of his particularly strong relations with the Benedictines and the Carmelites, from around 1620 until the early 1640s.

Partly written before 1642 and prepared for publication in 1651, The Life of Lady Lucy Knatchbull was Matthew's first venture into original biographical writing. Knatchbull (1584-1629) was the first Abbess of the English Benedictine convent at Ghent, which she colonized with three other professed nuns in January 1624 as a division of the Brussels community, begun in 1598 by Lady Mary Percy (c. 1570-1642). Matthew may have first met Knatchbull in January 1619, after he had left England for Brussels. He soon became her spiritual director, supplying her with the proper reading matter, including The Penitent Bandito (St. Omer, 1620), his translation of Giuseppe Biondi's story of the conversion and death of Troilo Savelli, a Roman baron. But Matthew's connections with the Brussels convent dated back to well before 1619 : in 1611 he had sent an account of his widely publicized conversion to one of the nuns, Dame Mary Gage (c.1586-1614), sister to his inseparable companion George Gage. ${ }^{6}$ As the editor of The Life points out, both Benedictines and Teresians were influenced by Italian and Spanish revivalist currents and "moulded by the disciplinary enactments of Trent." "[W]hosoever will take the pains and pleasure to read St. Teresa's Life, of the Flaming Heart”, Matthew remarked, will discover that Knatchbull and Teresa "for Quality, and Kind" are "as like one another... as even two drops of water can be" (Part 2, 124).

The item of recommended reading was his own The Flaming Hart or the Life of the Glorious S. Teresa, Foundress of the Reformation, of the Order of the All-Immaculate Virrgin-Mother, our B. Lady, of Mount-Carmel (Antwerpe : Iohannes Meursius [Jan van Meurs], 1642). "M.T." dedicated the work to no less a person than "the incomparable, soveraigne Princesse, Henrietta-Maria of France, Queen of Great Brittaine”, emphasizing her affection for "the holy Religious woemen of her [St Teresa's] Angelicall Order; whereof, the English nation...hath a Monastery at Antwerpe." (*2v). In the "Preface of the Translator", he interestingly revealed the circumstances of composition: "I was moved (and who would not be moved?) by the reverend Mother Superiour of the English Teresian-Carmelites, at Antwerpe, \& the rest of that holie Assemblie, to Translate, out of Spanish, into English, the

\footnotetext{
${ }^{6}$ Mathew and Calthrop, 69ff; see also Vander Motten and Daemen- De Gelder, 20-30.

${ }^{7}$ Matthew, $\mathrm{x}$-xi.
} 
Life of the Admirable, and Blessed Woeman, S. Teresa." $(* 5 r)^{8}$ The work was designed to replace M[ichael] W[alpole]'s Lyf of the Mother Teresa of Iesus (Antwerp, 1611), which on account of its obscure passages and erroneous readings had not gone down well with the general reader, let alone the Carmel community. ${ }^{9}$ Evidently working at a feverish rate, Matthew completed his work "with all the care, \& speed, which I could possibly use" (*6r), over a year after his banishment to the continent in April 1641. ${ }^{10}$ Despite his best philological efforts, he also humbly noted that the original Vida de la Madre Teresa de Jesus (1590), by Teresa's confessor Francisco de Ribera (1537-91), still outdid his own "Plaine-Song, concerning the Saint." $(* * * 4 \mathrm{v})$.

That the reverend Mother Superior of the Antwerp Carmelites, Ann Worsley (1588-1644), Anne of the Ascension in religion, should have commissioned an English translation of Ribera's original will cause no surprise. Editions and translations of Teresa's writings, including Dutch and French versions, contributed to the wave of veneration, both before and after her canonization in March 1622. As early as 1607 Gaspar Bellerus, printer at Antwerp, brought out Jean de Brétigny's and Guillaume de Cheure's La vie de la mère Térèse de Jésus. In 1609 Roland van Overstraeten's Het leven van de moeder Teresa van Iesus, was published by Rutgeert Velpius in Brussels, followed by two more Dutch translations printed at Antwerp. One of these, Joachim Trognesius' Het Leven der H. Moeder Terese van Iesus Fundaterse van de Barvoetsche Carmeliten (1620), was prefaced with a Spanish dedication to the archduchess Isabella, who in 1607 had founded the Brussels convent of the Discalced Carmelites. A new English translation, then, commissioned by the English Carmel, executed by an accomplished hagiographer, and brought out by Jan van Meurs (fl. 1618-42), the distinguished printer-publisher of Jesuit books, would have been at once a forceful advertisement of the convent's English identity, a memorial to the collective lives of its members and a symbol of its prominent status in the Teresian cult. ${ }^{11}$ According to a historian of the Antwerp printing-press, it was "à la demande expresse de la mère supérieure des Thérésiennes Carmélites anglaises, établies à Anvers, qu'il [Meursius] se chargea de cette édition [The Flaming Hart]....Ce livre fut très répandu parmi les catholiques anglais." 12

Matthew had already offered convincing proof of his unwavering devotion to the Carmelites and his literary skills in his Life of the Holy and Venerable Mother Suor Maria

\footnotetext{
${ }^{8}$ The title-page of the copy reproduced on Early English Books Online has the handwritten inscription "Belonging to the English Teresians at Antwerp".

${ }^{9}$ On the authorship of Walpole's work, see Spinnenweber.

${ }^{10}$ Loomie. The "Approbatio" by Richard Wake is dated 5 August 1642.

${ }^{11}$ On material memorials as the "children" of religious women, see Dolan, 334.

${ }^{12}$ Sabbe, 69.
} 
Maddalena de Patsi (s.l. [Cologne?], 1619). ${ }^{13}$ One of the most charismatic figures in Carmelite history, Mary Magdalen (Catherine) de' Pazzi (1566-1607) was a contemplative and mystic, whose Ecstasies had been part of the Vita published at Florence by her confessor Vincenzo Puccini in 1611. Even before her beatification in 1626, portraits and designs made her the subject of a cult which spread rapidly through Italy, France, Spain and Flanders. In centres of devotion in Ghent, Brussels and Antwerp, an extensive iconography, including engravings and stained-glass windows, developed around her in the latter half of the seventeenth century. ${ }^{14}$ Preceding the first Dutch version of Puccini's biography (Antwerp, 1628) by nine years, Matthew's translatio princeps took pride of place in the spate of writings publicizing her fame in the Low Countries and beyond. Coincidence or not, his translation appeared in the year the Antwerp Carmel was founded.

In addition to the Lives of St. Teresa and Catherine de' Pazzi, Matthew also wrote a memoir of one of the Antwerp community's most inspiring and devout members. This memoir is contained in an unpublished chronicle preserved in the Antwerp city archives and entitled "Short Colections of the Beginings of Our English Monastery of Teresians in Antwerp with some few perticulars of our Dear Deceased Religious". ${ }^{15}$ The book, nicely bound in brown leather and fastened with two clasps, is written in the same regular and clear hand throughout. It has five preliminary sheets and pages numbered 1 to 655 . The length of the chronicle with its seventeen ink drawings -- some signed by the Antwerp book illustrators Cornelis Galle and Peter Balthazar Bouttats (1666-1755) -- reveal the care lavished upon the book by the community that produced it. The presence in the chronicle of these two artists indeed offers proof of the Carmel's connections with the contemporary Antwerp art scene. Cornelis Galle, father (1576-1650) and son (1615-1678), both produced an extensive oeuvre of portraits and prints, many intended as title-pages and vignettes for Catholic books of devotion. For some of their subjects they turned to Carmelite sources of inspiration : Galle senior's illustration(s) in Petrus Wemmers' Dutch translation of Puccini's Vita (Antwerp, 1643) is a case in point. It is

\footnotetext{
${ }^{13}$ The "Epistle Dedicatory" to Lady Mary Percy (see above) is signed "G. B." and dated "From Collen this 20 of April, 1619." G. B. had "receaved commandment from a dying Friend to publish this Translation...together with the Preface that goes before it." This "dying friend" was no doubt Matthew himself, who from February until July 1619 stayed in Brussels, bedridden with a serious illness: see Mathew and Calthrop, 162-9.

${ }^{14}$ Smet, 63-9.

${ }^{15}$ Felixarchief Antwerp, KK 1018 ("Engelse Theresianen, Kloosterkroniek"). An annotated edition of the complete text by Katrien De Gelder is forthcoming (Chatto and Pickering, 2013).
} 
inconceivable that the Antwerp Carmel in engaging the talents of Galle (either father or son) for some of the drawings in the chronicle did not have an eye to the spectacular series of twenty-five engraved plates illustrating the life of St Teresa, which Cornelis sr had brought out in co-operation with Adriaan Collaert (ca. 1560-1618) as early as $1613 .{ }^{16}$ A draughtsman and engraver, Peter Boutatts throughout his career worked for printers and publishers at Antwerp, Brussels and Ghent, supplying them with frontispieces and plates representing coats of arms, historical scenes, and Catholic prelates as well as a long list of martyrs and saints, including Teresa and Mary Magdalen de' Pazzi. Accompanying the life of Mary Margaret of the Angels (1617-1678) is a drawing by Bouttats showing the nun's "Corps non corrompu...comme il a été trouvé 38 ans après sa mort le 13me d'Août 1716". Designed to put readers into direct contact with this miraculous occurrence, "cette figure", the subscription further explains, "a touché au dit Corps" (unnumb. page). ${ }^{17}$ We do not know when or upon what terms Bouttats and Galle, decades apart, were drawn into the convent's historiographical effort but their contribution would undoubtedly have been regarded as a telling graphical record helping to keep the memory of the Antwerp Carmel alive.

Underlying the chronicle, which was begun around 1730, was a remarkably scrupulous process of "narrative restoration". Its compiler, Sister Mary Joseph of St Teresa (Mary Howard, 1688-1756), urged on by Prioress Mary Frances (Mary Birkbeck, 1674-1733) and Father Percy Plowden (1672-1745), the convent's spiritual director, made extensive use of existing institutional (rules and constitutions), conventual (necrologies) and individual papers (letters, devotions, confessions) to compose the history of Antwerp's English Carmelite foundation. ${ }^{18}$ The chronicle contains the lives of ninety-five nuns and lay sisters who professed there between 1619 and 1721. Although it is doubtful whether this was the master manuscript from which other copies such as the Lanherne annals now preserved in $\mathrm{St}$ Helens Carmelite Convent, Merseyside were made, it may well have served as the Antwerp convent's main copy. It is in any case the book that was taken to Rome in 1731 - the compiler interrupting her work for several years - to be shown to Father Plowden, by then rector of the English college, "that he might see it and how we hav[e] endeavour'd to put in execution what he so often and earnestly recommended to us" (576-7).

\footnotetext{
${ }^{16}$ De Busscher, "Galle", 449-56. For a full survey, see the British Museum collection database.

${ }^{17}$ De Busscher, "Bouttats", 889-90, mentions the existence of this etching but does not specify its whereabouts. Mary Margaret was the daughter of Lionel Wake, one of the executors of Matthew's will (see note 31). She had entered the Carmel on 10 June 1633, and was prioress there from 1655 until 1671: see Geloof en Leven 107 (2003), no. 3.

${ }^{18}$ The subdivision is Hallett's, 8 .
} 
The annals cover nearly the entire recusant period in which the Carmelites, like virtually all other English nuns of the era, resided in expatriate religious communities. The chronicle plainly shows the extent to which these women's lives were directly affected by the rigours of exile - "drawing together so many happy chosen souls from an unfortunate Heritick Countery where so much blindness and wickedness reigns that nothing but a strong ray of Divine grace could effect it" (ibid.) - and the bitter religious issues and political struggles of the period. It therefore provides an essential contextual framework within which to read and analyse the foundational papers as well as the lives. The annals were obviously put together for preservation and edification purposes, so 'that what we found and knew of might not be forever lost, to the end that those present and those who shall follow may be animated with the Primitive Spirit and fervour courageously to follow the examples of these their predecessors' (unnumb. prelim. page). They commemorate the establishment of the English Carmel in 1619 and throughout underscore the nuns' fidelity to the Carmelite reform. Commenting favourably upon its conception - "the Book is as well writ as it need to be, and if it were in a finer stile, perhaps it would not edify so much" (576-7) - and holding up the nuns' unblemished piety as a model for emulation, Plowden's recommendation was that the chronicle be "read over once a year in the Refectory" (ibid.). In foregrounding the importance of their intense spiritualism in their prayers, meditations and mystical encounters (some more spectacular than others), the Antwerp Carmelites also hoped to attract new entrants.

Included in the chronicle is a "little relation" of Sister Agnes of Saint Albert, "writ by $S^{\mathrm{r}}$ Toby Matthew who was a Jesuett but not publickly known to be so one who had a singular love and affection for the Community and a great devout of our Holy Mother $S^{t}$ Teresa.” (315). Sister Agnes (1615-42), “in the world Agnes Vivine Roosendael Daughter of Mr Theodorus Roosendael and of Agnes Martins [Martens?] native of Antwerp in Brabant", made her holy profession on 31 January 1632. The relation was written "soon after her happy death" (298) in April 1642. ${ }^{19}$ Whether what we have here is the original text cannot be ascertained; some editing may have taken place in the intervening years. The paragraphs dealing with "some few things not coming to his [i.e. Matthew's] knowledge concerning Sister Agnes" (315) and appended to the Life suggest, however, that the body of the text itself was largely left untouched. That the compiler should have named Matthew as the author of the Life testifies to the respect in which he was held by the Order, some seventy-five years

\footnotetext{
${ }^{19}$ Excerpts from the Life in the Lanherne version are included in Hallett, 79-81.
} 
after his death and burial at Ghent, in 1655. With its authorship thus established, this item may confidently be added to the canon of Matthew's works.

Matthew's memoir consists of three discrete sections : Agnes's youth and early education; her vocation and the circumstances of her entrance into the Antwerp Carmel; and her martyrdom and death. Section one relates the orphaned, thirteen year old, "mademoiselle Roosendael's" education in a Brabant monastery, where she soon recognized the importance of poverty as a way to perfection -- a virtue less than strictly practised by the religious women there. These ladies indeed were "not only desirous but earnest to continue her amongst them" as she was an "amiable creature" possessed of a "very advantageous" fortune (299). Section two deals with the resistance Agnes encountered once she had decided to become a Teresian. She forced herself upon the Carmel at the age of sixteen, imploring Mother Superior to admit her against the express wishes of her confessor as well as her friends and relatives, who hoped to keep her fortune for themselves. Once admitted by special permission of the Bishop of Antwerp, she proved an extraordinary creature, pious, graceful, and loving --all after the example of St Teresa. "I tell myself often that if Sister Agnes of St Albert were not one of the sincerest creatures that ever I saw, she was one of the greatest hypocrites that ever I knew" (311), Matthew strangely noted. The third section recounts the circumstances of her death. Her life, guided by poverty, chastity, obedience and enclosure, was that of a martyr; the suffering accompanying her death marked her out as a saint, who already in this life enjoyed St Teresa's succour. ${ }^{20}$ Reminding his audience of Agnes's strict observance of the Order's solemn vows, the intruding narratorial voice left no doubt that his subject was destined for sainthood all along. Matthew's pious biography, one of the more extensive accounts in the chronicle, was likely composed by invitation of the Order, who were eager to hold up this zealous follower of St Teresa as a model for imitation. In Matthew's hands, however, her story became the occasion to pay fulsome tribute to the Antwerp Carmel itself, which is made to contrast favourably with another (unnamed) monastery lacking in discipline and even with other Carmelite houses. Just as Agnes's exemplary conduct proved "a great support ... in a time when the Community was put to great Straits" (317), so Matthew's contribution to

\footnotetext{
${ }^{20}$ Probably an authentic detail, Agnes's spreading her arms in the form of a cross shortly before her death is reminiscent of St Teresa's posture in the many representations of her martyrdom. The social standing of Agnes's family would have increased the attractiveness of her story : see van Wyhe, 478.
} 
Carmelite historiography was intended as an act of gratitude to this community, who had given him physical and spiritual shelter. ${ }^{21}$

The materials incorporated in the biography would have derived from multiple sources : the other nuns, Agnes's own testimony, and the various "Ghostly Fathers" who had inspected "the account of her whole life" (317). Occasional passages of direct speech lend authenticity to the Life and were probably gleaned from notes taken by her confessors, before and after her entrance. Perhaps Matthew obtained first-hand information as the nun's spiritual guide, even though his name does not appear on the (eighteenth-century) list of confessors included in the chronicle (157-60). One aspect of her life that, for obvious reasons, touched him closely was the sense of alienation she must have experienced. Antwerp-born Agnes, he pathetically recorded, "threw herself headlong away amongst strangers, for so were the English to her" yet "she carried... a tender affection to our Nation" (315). This predicament was remarkable enough to have already attracted another writer's attention. Ten years earlier John Falconer (1577-1656), a fellow-Jesuit, had spoken in praise of Sister Agnes in The Mirrour of Created Perfection. Or The Life of the most Blessed Virgin Mary Mother of God [Saint-Omer : English College Press, 1632]. ${ }^{22}$ Dedicating his work "To the Vertuous and Religious Sister, Agnes Rosendale Now Called Sister Agnes of St. Albert, native of Brabant, \& Religious in the Monastery of English Carmelites at Antwerpe", Falconer within months after her profession fastened upon Agnes's "heroicall resolution" to enter the monastery and her abandonment of "worldly friends, and temptations" as an exhortation to affluent "English gentlewomen" to follow suit ("The Epistle Dedicatory", *3). In composing his account, Matthew evidently had an eye to this dedication, written by a well-informed fellow-exile who had ministered at Agnes's "nuptials" in January 1632. Not only did he repeat the quotation from St. Bernard's ("they looke upon our crosses, but know not our comforts", *5v) emphasizing the many consolations of a cloistered life. He also reiterated Falconer's idea that Agnes had "in a sort" left her country and friends, as the other nuns had left theirs, "by living so amongst strangers in it, as if [she] were quite out of it [i.e. her country]" (*6v). Unlike Matthew, Falconer did not set out to proselytize on behalf of the Antwerp Carmel but, by way of his young dedicatee, of monastic life in general. But his decision to dedicate his work to

\footnotetext{
${ }^{21}$ To show his recognition, Matthew in 1642 donated a piece of St Teresa's heart, the transverberated organ : see Majérus, 178. In January 1644 an order for a reliquary, worth two hundred and forty florins, was placed with the renowned Antwerp goldsmith Theodoor Rogiers (1602-c.1654). As Wilson observes, such relic "must have fueled local devotion to Teresa's best-known mystical experience", 220.

22 Between 1631 and 1648 Falconer, who had been ordained in 1603, served in several capacities at English Jesuit houses in Ghent, Liège and elsewhere : see McCoog.
} 
Agnes, "as a sincere testimony of my Religious respect, unto you, and that holy family" (*4v*5r; italics added), was inspired by feelings of thankfulness for the "temporall meanes" with which she had apparently supported him. Both men, interestingly, alluded to their respective position as a "poore Exile" or "Stranger" ten years apart -- reminding us how the nature of their occasional writings was co-determined by their expatriate status, specifically their association with the Antwerp Carmel community. John Falconer indeed may have been the "Holy Priest", mentioned in the addition to Matthew's account, who knew "all the particulars of [Agnes's] vocation [and] painted with his own hand a great many very fine Emblemes expressing the same with mottos truly presaging her Holy life and happy death, and presented them to her at her profession." (316) ${ }^{23}$

Selective, episodic, and didactic, Matthew's seventeen-page narrative is representative of this type of early modern hagiographical text. ${ }^{24}$ Less ambitious than his other works, it nevertheless illustrates just as pertinently his participation in the monastery's daily life and his concern for its members. ${ }^{25}$ When read alongside the memoir, Matthew's will dated October 1647 deserves renewed consideration, highlighting as it does his close involvement with the Antwerp Carmelites. ${ }^{26}$ Matthew earmarked the "first money" proceeding from his estate, i.e. after payment of his debts, for the printing of

all the workes of my glorious Mother St Teresa (whereof I translated the most part of, at the instance of my most deare and most deserving freind, Sister Ann of the Ascension, Religious of the English Teresian monestery att Antwerp), and that all I have in written hand, as an encrease of portion to my deare late Novice sister Ann of Jesus, all which are now in the said Monastery...[italics added]

In addition, he left a legacy of six hundred pounds "to the Teresians, or rather to the new monestary [sic] where Sister Ann of the Ascension may be" [italics added]. Sister Ann of the Ascension, the "most deare...friend" at whose behest he translated most of St Teresa's works, was Catherine Keynes (1619-68), the second of that name. ${ }^{27}$ Sister Ann of Jesus was Ann Keynes (1628- ?), Catherine's sister, who had been a "late" novice until 1645, the year in which she took her vows. According to the Antwerp chronicle, "she had a great

\footnotetext{
${ }^{23}$ It may be noted that Antwerp in this period saw the production of numerous emblem books by the Jesuits and other orders : see Meeus, 239.

${ }^{24}$ Bilinkoff, passim.

${ }^{25}$ Matthew was obviously on good terms with other members of the community : he attended the examination preceding the profession of Anne Somerset (1613-51), Anne of the Angels in religion, the daughter of Henry Somerset, Earl of Worcester, and his wife Ann. She professed on 8 October 1643 : see Hallett, 87.

${ }^{26}$ The text of the will is included in Mathew and Calthrop, 337-41.

${ }^{27}$ The first prioress, Sister Ann (Worsley) of the Ascension, had died in 1644. Matthew may have known Catherine's younger brother John Keynes (1624-97), also a Jesuit and religious controversialist : see Blom. Catherine Keynes was chosen superior in 1650, and continued so for nine years.
} 
understanding", and was "an extreme pretty writer and a very fine Poiet as her many charming songs upon all subjects shews."(437) It may have been this poetical talent which commended her to Matthew's attention. Even so, his appointment of Ann Keynes as his "curator" evinces a remarkable degree of confidence in her bibliographical competence to collect and organize his incomplete papers, and prepare them for the press. Perhaps, as in the case of Walpole's 1611 translation of St Teresa's Life, Carmelite patronage of Matthew's Teresian writings had gone beyond the mere act of commissioning to encompass a nearcollaborative form of 'technical' assistance. ${ }^{28}$

Little attention has been given to Matthew's claim that in addition to St Teresa's Life he had been working on a translation of other works by her as well as a biography of St. Augustine, whose Confessions he had published in translation in $1620 .^{29}$ Equally neglected is the fact that the will establishes beyond doubt that the Antwerp Carmel was a fertile breeding-ground for Matthew's contributions to the devotional literature of the Catholic Reformation. Capitalizing on the popularity of Teresian writings, the monastic authorities at Antwerp actively stimulated the composition of some of Matthew's hagiographical works. Published under the aegis of the Carmelites, these works would have helped raise the prestige of the recently founded house, investing it with the spiritual and cultural authority both to speak out for the Counter-Reformational cause in the Low Countries and to address the Catholic brethren at home. ${ }^{30}$ By enlisting a writer and public figure as well-connected and widely travelled as Matthew, the Carmel no doubt also expanded -- or consolidated -- its social networks, drawing into its orbit local artists and benefactors as well as high ecclesiastical functionaries. ${ }^{31}$

\footnotetext{
${ }^{28}$ Spinnenweber, 6.

${ }^{29}$ As part of his other compositions and translations, Matthew bequeathed to Sir Walter Montague (1604/5-77) a half-finished Life of the saint, asking to have his manuscripts "perused and well considered" and to have "such of them ...printed, as he and Mr Hall shall think fit" (Mathew and Calthrop, 339). There is no indication, however, that these were kept at Antwerp.

${ }^{30}$ The anonymous Missive of Consolation Sent from Flanders, to the Catholikes of England (Louvain, 1647) has been attributed to Matthew. In the "Preface to the Reader" the author alludes to his "Out-landish accent", "having beene nursed with many severall milks, and sucked but little at the breasts of my Mother; but ... from the breast of my spirituall Mother, the Roman Catholique Church." (A4v)

${ }^{31}$ A churchman, an art broker and a co-religionist were appointed as executors of the will : "Mr Henry Taylor, Channon of St Gudala in Brussels and Chappllin of honour in the Royall pallace of that Court", "Mr Francis Playdon, the younger, of Shiplak in the county of Oxford, Esqr" and "Master Lyonall Wake in Antwerp." The first was Henry Teller, appointed archduchess Isabella's agent in London in February 1631. In 1640 the new
} 
Although doubly insulated from the world, by enclosure and obedience to the rule as well as by its English character, the Antwerp Carmel was by no means cut off from its surroundings. A careful perusal of its annals and of the vast correspondence left by the women religious confirms that the convent functioned as an intellectual meeting-point, exposing an interesting jigsaw of intersections between the private and the public, and the religious and cultural worlds of the early modern period. Throughout the century, writers and graphic artists were called upon at one time or another to contribute to the creation (and in the case of the patrons, the financing) of a variety of Carmelite cultural artifacts - translations, memoirs, illustrations, emblems, and engravings. ${ }^{32}$ Although the available evidence is still fragmentary, it appears that the Antwerp Carmel not only drew on the cultural resources of the local community but also on the creative zeal of their expatriate fellow-countrymen, who could carry out their work virtually unopposed in the Spanish Netherlands. The new evidence presented here suggests that the cultural connections between the convent and the outside community was indeed a two-way traffic. The to-and-fro on which such exchanges are predicated would have necessitated a fairly continuous policy of openness on the part of a house that set great store on enclosure. While this goes to confirm Hallett's remark that enclosure was often "broken", for instance "when seculars...entered to meet with the nuns", it also implies that such "seculars" were not only "royal, noble or well-connected ones" 33 . As far as the Carmelite sisters themselves are concerned, like all other women religious they wrote as members of their order rather than as individuals and the genres they worked in were consequently "determined by community audience". ${ }^{34}$ The formidable array of hitherto unpublished documents in the Antwerp chronicle and the strong indications they provide of cross-channel and South-Netherlandish cultural contacts underscore the need for a redefinition of the "entrepôt" concept to include self-sustaining, i.e. semi-secluded and partially independent, cloistered communities, whose long-lasting intellectual significance

governor, Cardinal-Infant Ferdinand, recommended him to the post of canon of the chapter of Sint-Goedele in Brussels : see Lefèvre and Houben. Lionel Wake sr was an English merchant in Antwerp, who frequently transmitted pictures by Rubens. Having dealt with Wake since 1617, Matthew in his will thanked the family for having received him "into their house for the greatest part of this last year" (Sainsbury, 21). Francis Playdon cannot be reliably identified but he may be the "Francis Playdon esq." mentioned in a list of "persons to be indicted for recusancy" dated 1 October 1635: see "Particulars from the Process Book: 1631-41", Middlesex Count Records: Volume 3: 1625-67 (1888), 128-59.

\footnotetext{
${ }^{32}$ The Antwerp painter Abraham van Diepenbeeck (1596?-1675) created a prodigious number of "Carmelite related designs", including a Vita Seraphicae Virginis Sanctae Mariae Magdalenae de Pazzis (Antwerp, 1670?), a (collaborative) series of forty-eight plates depicting the saint's life and commemorating her canonization in 1669

http://carmelites.info/museum/gallery.leading figures/gallery.mmpazzi/exhibition.mmpazzi.diepenbeeck.htm.

${ }^{34}$ Coolahan, 9, $78 \mathrm{ff}$.
} 
was not necessarily tied up with individual interests, literary fashions or political expediency. Until further and more detailed evidence emerges, is it too far-fetched to suggest that the cultural world of the Antwerp Carmel was a microcosm of the seventeenth-century city itself, a transit route or clearing-house not just of material goods but also of ideas and works of art?

\section{References}

Bilinkoff, Jodi. Related Lives. Confessors and Their Female Penitents, 1450-1750. Ithaca, N.Y.: Cornell University Press, 2005.

Blom, F. J. M. and J. M. Blom, "Keynes, John (1624-1697)." Oxford Dictionary of National Biography. Oxford: Oxford University Press, 2004 [http://www.oxforddnb.com/view/article/15502].

Coolahan, M.-L. Women, Writing and Language in Early Modern Ireland . Oxford: Oxford University Press, 2010 .

Crashaw, Richard. "The Flaming Heart. Upon the Book and Picture of the Seraphicall Saint Teresa." In Carmen Deo Nostro, Te Decet Hymnus. Sacred Poems. Paris, 1652.

De Busscher, Edmond. "Bouttats." Biographie Nationale. Tome Deuxième. Bruxelles: Thiry-Van Buggenhoudt, 1868.

."Galle." Biographie Nationale. Tome Septième. Bruxelles: Bruylant-Christophe, 1880-3.

Dolan, Frances E. "Reading, Work, and Catholic Women's Biographies." English Literary Renaissance 33 (2003): $328-57$.

Guilday, Peter. The English Catholic Refugees on the Continent 1558-1795. Vol. 1, The English Colleges and Convents in the Catholic Low Countries, 1558-1795. London: Longmans, Green, 1914.

Hallett, Nicky. Lives of Spirit. English Carmelite Self-Writing of the Early Modern Period. Aldershot: Ashgate, 2007.

Houben, Birgit. "The Courts and Households of the Widowed Infanta Isabella and the Cardinal-Infant Don Fernando of Austria (1621-1641).” http://www.lowcountries.nl/papers/2006-1_raeymakers.pdf].

Lefèvre, Joseph. "Henri Teller, Doyen d'Anvers et Diplomate (1598-1662)." Archives, Bibliothèques et Musées de Belgique 13, no. 2 (1936): 89-104.

Loomie, A. J. "Matthew, Sir Toby (1577-1655)." Oxford Dictionary of National Biography. Oxford: Oxford University Press, 2004 [http://www.oxforddnb.com/view/article/18343].

Majérus, Pascal. Ordres Mendiants Anglo-Irlandais en Belgique. Bruxelles: Archives générales du royaume, 2001.

Mathew, A. H. and Annette Calthrop. The Life of Sir Tobie Matthew. Bacon's Alter Ego. London: Elkin Mathews, 1907.

Matthew, Sir Tobie. The Life of Lady Lucy Knatchbull. Edited by Dom David Knowles. London: 1931.

Meeus, Hubert. "Antwerp as a Centre for the Production of Emblem Books." Quaerendo 30 (2000) : 228-39. 
McCoog, Thomas M. "Falconer, John (1577-1656)." Oxford Dictionary of National Biography. Oxford: Oxford University Press, 2004 [http://www.oxforddnb.com/view/article/9112].

Sabbe, Maurice. "La Typographie Anversoise au XVIIe et au XVIIIe Siècle." In Histoire du Livre et de L'Imprimerie en Belgique des Origines à nos Jours. Quatrième Partie. Bruxelles: Le Musée du Livre, 1925-26.

Sainsbury, W. Noël, ed. Original Unpublished Papers Illustrative of the Life of Sir Peter Paul Rubens, as an Artist and a Diplomat. London: Bradbury and Evans, 1859.

Saint Teresa. The Life of St. Teresa of Jesus, of the Order of Our Lady of Carmel. Written by Herself. Translated from the Spanish by David Lewis. With Additional Notes and an Introduction by Rev. Fr. Benedict Zimmerman. 3rd ed. London: T. Baker, 1904.

Smet, Joachim. Cloistered Carmel. A Brief History of the Carmelite Nuns. Rome: Institutum Carmelitanum, 1986.

Spinnenweber, Kathleen T. "The 1611 English Translation of St. Teresa's Autobiography : A Possible Carmelite-Jesuit Collaboration." SKASE Journal of Translation and Interpretation 2, no.1 (2007) [http://www.skase.sk/Volumes/JT102/pdf_doc/1.pdf].

Vander Motten, J. P. and Katrien Daemen-De Gelder. "Sir Toby Matthew and His "Fidus Achates" George Gage, 1607-1620." American Notes and Queries 23 (2010) : 20-30.

Winston, Christopher C. "Saint Teresa of Avila's Martyrdom : Images of Her Transverberation in Mexican Colonial Painting." Anales del Instituto de Investigaciones Estéticas 21 (1999) : 211-33.

Wyhe, Cordula van. "Piety and Politics in the Royal Convent of Discalced Carmelite Nuns in Brussels, 16071646." Revue d'Histoire Ecclésiastique de Belgique 100 (2005): 457-87. 